\title{
AGC2 (Citrin) Deficiency-From Recognition of the Disease till Construction of Therapeutic Procedures
}

\author{
Takeyori Saheki ${ }^{1, *}$, Mitsuaki Moriyama ${ }^{2}$, Aki Funahashi ${ }^{1}$ and Eishi Kuroda ${ }^{1}$ \\ 1 Department of Hygiene and Health Promotion Medicine, Kagoshima University Graduate School of Medical \\ and Dental Sciences, 8-35-1 Sakuragaoka, Kagoshima 890-8544, Japan; aki.2784@gmail.com (A.F.); \\ kurodaeishi1029@yahoo.co.jp (E.K.) \\ 2 Laboratory of Integrative Physiology in Veterinary Sciences, Osaka Prefecture University, 1-58 \\ Rinku-oraikita, Izumisano, Osaka 598-8531, Japan; moriyama@vet.osakafu-u.ac.jp \\ * Correspondence: takesah@gmail.com; Tel.: +81-99-275-5291
}

Academic Editor: Ferdinando Palmieri

Received: 4 June 2020; Accepted: 19 July 2020; Published: 24 July 2020

\begin{abstract}
Can you imagine a disease in which intake of an excess amount of sugars or carbohydrates causes hyperammonemia? It is hard to imagine the intake causing hyperammonemia. AGC2 or citrin deficiency shows their symptoms following sugar/carbohydrates intake excess and this disease is now known as a pan-ethnic disease. AGC2 (aspartate glutamate carrier 2) or citrin is a mitochondrial transporter which transports aspartate (Asp) from mitochondria to cytosol in exchange with glutamate (Glu) and $\mathrm{H}^{+}$. Asp is originally supplied from mitochondria to cytosol where it is necessary for synthesis of proteins, nucleotides, and urea. In cytosol, Asp can be synthesized from oxaloacetate and Glu by cytosolic Asp aminotransferase, but oxaloacetate formation is limited by the amount of $\mathrm{NAD}^{+}$. This means an increase in NADH causes suppression of Asp formation in the cytosol. Metabolism of carbohydrates and other substances which produce cytosolic NADH such as alcohol and glycerol suppress oxaloacetate formation. It is forced under citrin deficiency since citrin is a member of malate/Asp shuttle. In this review, we will describe history of identification of the SLC25A13 gene as the causative gene for adult-onset type II citrullinemia (CTLN2), a type of citrin deficiency, pathophysiology of citrin deficiency together with animal models and possible treatments for citrin deficiency newly developing.
\end{abstract}

Keywords: adult-onset type II citrullinemia (CTLN2); aspartate/glutamate carrier (AGC); animal model; argininosuccinate synthetase (ASS); aversion to carbohydrates; citrin; food taste; neonatal intrahepatic cholestasis caused by citrin deficiency (NICCD)

\section{Introduction}

AGC2 or citrin deficiency is the most prevalent autosomal recessive inherited metabolic disease in East and East-south Asia and it is now known as a pan-ethnic disease [1-9], and is one of the many diseases caused by mutations in the genes encoding members of the SLC25 protein family $[10,11]$. Its heterozygote frequency in East Asia is up to 1 in 40 [12,13]. There are mainly 2 disease types, CTLN2 (adult-onset type II citrullinemia) and NICCD (neonatal intrahepatic cholestasis caused by citrin deficiency) [14-17]. Citrin deficiency also causes FTTDCD (failure to thrive with dyslipidemia caused by citrin deficiency) [18], pancreatitis [19], NASH [20,21], and hepatoma [22,23]. In this review article, we will describe AGC2 or citrin deficiency starting from the recognition of the disease, discovery of the disease gene for CTLN2 and to pathophysiology of the disease based on the function of AGC2, and therapeutic procedures derived from analysis of food preference. 


\section{Materials and Methods}

Materials and Methods are described in each publication. Human patients and mice are analyzed. Informed consents of all subjects are obtained. Animal experiments were done after getting approval of committee of animal experiment at Kagoshima University, Tokushima Bunri University, and Kumamoto University.

\section{Study Started from Enzymology of Argininosuccinate Synthetase (ASS)}

Saheki et al. started purification of ASS from rat and human liver in 1973 [24] on the assumption that since ASS activity is the lowest among the urea cycle enzymes, ASS may be tightly regulated by some factors. We purified the enzyme to a homogeneity and crystalized, but they could not find any significant regulatory mechanism in the ASS protein. During the research, we have been asked by many clinicians or clinical researchers whether the hepatic ASS activity of their citrullinemic patients is low or not, since the enzyme catalyzed the synthesis of argininosuccinate from citrulline and Asp in the expense of ATP breakdown. Since ASS deficiency is assumed to cause citrullinemia, Saheki et al. examined $\mathrm{Km}$ values for citrulline, Asp, and ATP, and quantified the ASS protein amount by using anti-ASS antiserum together with assaying ASS activity. Luckily enough, we noticed there are two types of enzyme abnormality in the patients' ASS in the liver obtained by biopsy or autopsy almost from the beginning [25]. As you see in Table 1, one group is mainly from neonates, the low ASS activities were from lowered affinities to the substrates, citrulline, Asp, or/and ATP, or enlarged Km values for the substrates. Using autopsied samples, we also examined kidney and brain ASSs, which showed the same abnormalities in the enzyme kinetics. The same abnormalities were found in the cultured skin fibroblast cells [26]. The enzyme amounts are normal (type I) or very minute amounts (type III) are found. These results suggest that the abnormality is in the gene of ASS1. Kobayashi et al. [27] found real mutations in the ASS1 genes. So, this is classical or neonatal citrullinemia (CTLN1). The other group, named as CTLN2 later, consisted from mainly adult patients, showed reduced ASS activities which are explainable with the reduced enzyme amount with normal kinetic properties (type II). ASS activities in the brain, kidney, or cultured fibroblast cells are not different from the control. So that the former should be qualitative abnormality caused by mutations in the ASS1 gene and the latter is quantitative abnormality. Increased urinary excretion of argininosiccinate [28], the product of ASS reaction, in CTLN2 patients probably suggests normal operation of renal ASS reaction. The number of patients were much larger in the latter group. The symptoms of the latter group are consciousness disturbance and abnormal behavior with hyperammonemia, mild citrullinemia, and mild liver damage. From these enzymological abnormalities and clinical symptoms, we named it adult-onset type II citrullinemia, or CTLN2.

Table 1. Two distinct types of citrullinemia.

\begin{tabular}{|c|c|c|c|}
\hline $\begin{array}{l}\text { Type of Enzyme Abnormality } \\
\text { We Named: }\end{array}$ & Type I & Type III & Type II \\
\hline ASS activity or enzyme amount: & Abnormal kinetics & Almost null & Decrease of normal ASS \\
\hline Organ specificity & All cells & All cells & Liver-specific \\
\hline Type of abnormality & \multicolumn{2}{|c|}{ Qualitative } & Quantitative \\
\hline Disease: & \multicolumn{2}{|c|}{ CTLN1 (Classical citrullinemia) } & $\begin{array}{l}\text { CTLN2 (Adult-onset type II } \\
\text { citrullinemia) }\end{array}$ \\
\hline Gene: & \multicolumn{2}{|c|}{ ASS1 } & SLC25A13 (Citrin deficiency) \\
\hline
\end{tabular}

Before we have genetic information of the disease, we have several important information; for example, the patients showed high serum PSTI (pancreatic secretory trypsin inhibitor) [29], which is secreted not from the pancreas, but from the liver [30]. This is considered an early marker of disease onset [31]. 
In our group, Dr. Keiko Kobayashi et al. [32-34] performed molecular genetic analysis on these patients after earlier biochemical analysis on the mRNA and protein and found various mutations in the ASS1 gene in the former group patients, amino acid substitutions in ASS abnormality in its kinetic parameters, splicing site mutations in ASS abnormality with a very minute enzyme amount. They did similar analyses on the samples from patients with type II citrullinemia [35]. Together with our first analysis showing that no abnormalities in the amount and translatable activity of the mRNA [36,37], we finally concluded that there are no abnormalities in the ASS1 gene in the latter group. Table 1 shows two distinct types of citrullinemia.

\section{Pathogenesis of Adult-Onset Type II Citrullinemia}

What is the primary defect in CTLN2? The decreased level of ASS protein in the liver of CTLN2 patients is in average $9 \%$ of the control level (from almost $0 \%$ up to $70 \%$ ). So far, we have not been able to find out the mechanism of the decrease. We thought that the mechanism is not known but should be caused by genetic abnormality because we have found many patients derived from consanguineous marriage, suggesting that it is an autosomal recessive trait. So, we started genomic analysis using homozygosity mapping with 18 DNA samples from CTLN2 patients derived from consanguineous marriage and DNA samples from control subjects. This homozygosity mapping analysis revealed the disease gene located at chromosome 7q21.3 [38]. The gene mutated in CTLN2 patients were searched for in collaboration with Drs. Steve Scherer and Lap-Che Tui, Toronto, Canada. Finally, Dr. Kobayashi found mutations in SLC25A13, which encoded mitochondrial transporter [38], which was published in 1999. The results found showed that among 18 samples from consanguineous marriage contained three heterozygotes, suggesting high prevalence of the disease [38].

A very similar gene, SLC25A12 [39], encoding aralar reported by del Arco, Spain, was published in 1998. Prof. Ferdinando Palmieri, Italy, proposed collaboration among three groups to elucidate the functions of citrin and aralar. The collaboration was successful to find that the two genes encode mitochondrial membrane aspartate glutamate carrier (AGC) [40]. Both aralar (AGC1) and citrin (AGC2) transports proton and Glu from intermembrane space of mitochondria into mitochondrial matrix and Asp from mitochondria matrix to mitochondrial intermembrane space [40], and both activated by calcium [38,41].

AGC1 (aralar) is expressed mainly in the brain, skeletal muscle, heart, and kidney, while AGC2 (citrin) is located mainly in the liver, kidney and heart. So that AGC1 is the brain/skeletal muscle-type and citrin is the liver-type. More precise distributions of aralar and citrin have been reported by Begum et al. [42] and Amoedo et al. [43].

Citrin deficiency causes CTLN2 (OMIM ID \#603471) and NICCD (OMIM ID \#605814) [1,14], while aralar deficiency is a rare disease causing global cerebral hypomyelination, developmental arrest, hypotonia, and epilepsy (OMIM ID \#612949) [44,45]. Lists of mutations in citrin deficiency and AGC1 deficiency can be found at http://www.hgmd.cf.ac.uk/ac/gene.php?gene=SLC25A13 and 12.

\section{Discovery of NICCD (Neonatal Intrahepatic Cholestasis Caused by Citrin Deficiency) and Citrin Deficiency Disease Types}

Since we have discovered the gene for CTLN2, we were very busy creating a diagnostic system for each mutation found in CTLN2 and found many CTLN2 patients not only in Japan, but also in China [3-5]. During this time, three pediatric doctors were interested in neonatal hepatitis or cholestasis during neonates. Prof. Tazawa [15] visited Kagoshima and assayed liver ASS activity of his neonatal patients but without any positive results, but later, we diagnosed with DNA diagnosis that his neonatal transient citrullinemia patients were really suffering from citrin deficiency. At the almost same time, we also diagnosed with DNA diagnosis that the transient citrullinemia patients of Dr. Ohura also had mutations in SLC25A13 [16]. We also diagnosed the patient of Dr. Tomomasa [17] as a citrin deficiency patient: the patient showed NICCD symptoms at his neonatal period and suffered from CTLN2 later at 16 years old. Thereafter, many NICCD patients have been found in Japan, China, Korea, and other countries [1,6,46-48]. 
Laboratory findings of the patients were positive signs of several neonatal mass screening tests such as tyrosine, phenylalanine, methionine, and threonine. Some showed galactosemia $[49,50]$ and cholestasis and bleeding diathesis [2]. Extremely high serum levels of $\alpha$-fetoprotein are impressive [1,51]. However, there was almost no increase in blood ammonia.

About $50 \%$ of NICCD patients were found at neonatal screening and about $40 \%$ were about several months with persistent jaundice [1]. Some were found later with failure to thrive and dyslipidemia (FTTDCC) [18]. Among them, a few, one in 100,000 to 200,000 as the incidence developed to CTLN2 at adult age (10 to 80 years old) with symptoms including hyperammonemia, consciousness disturbance, and abnormal behavior. During the period between NICCD and CTLN2, most of the patients showed almost no severe symptoms except tiredness and almost normal laboratory examinations [52]. However, most of citrin deficiency subjects showed peculiar food taste from about 1 year old. Both our nutritional assessment [53] on symptomless citrin deficiency subjects from 1 year old and 36 years old, and Nakamura et al. on CTLN2 patients [54] revealed reduced intake of carbohydrates, which is very important as a pathogenesis of citrin deficiency and for the treatment of citrin deficiency, as stated later. The peculiar food taste of citrin deficiency subjects is shown in Figure 1. The various disease types of citrin deficiency during lifetime are shown in Figure 2.

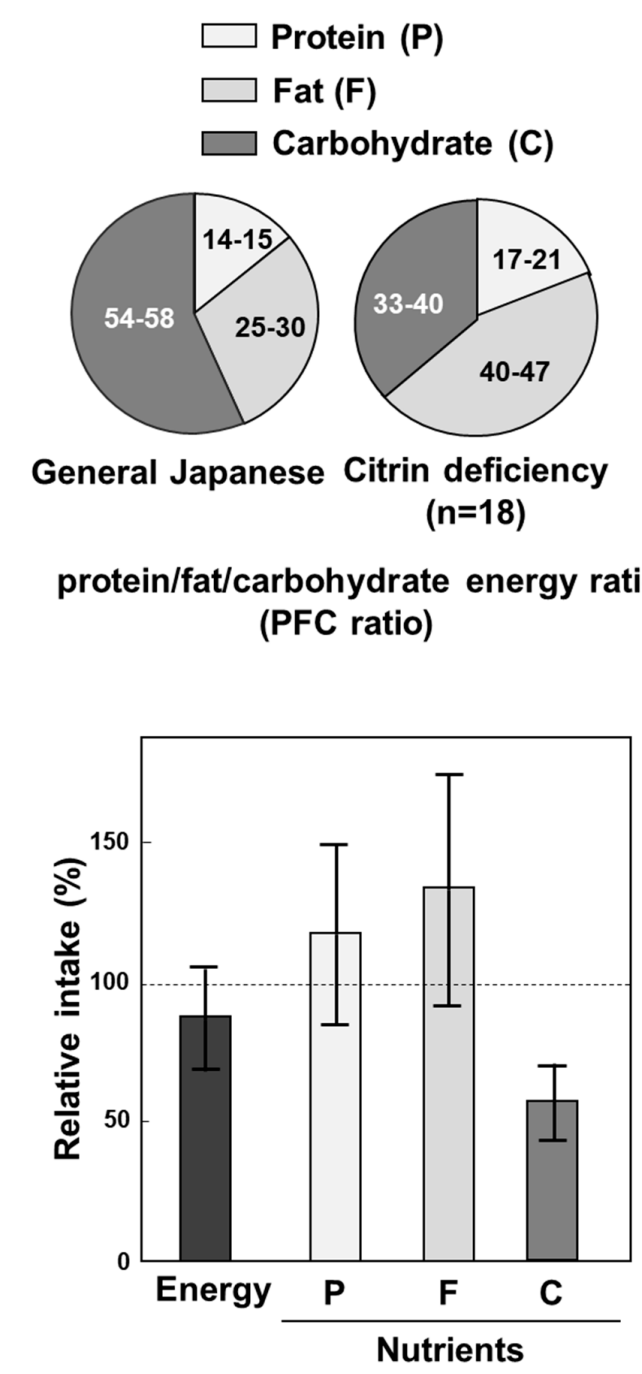

Figure 1. Peculiar food taste of citrin deficiency subjects. Upper panel shows protein, fat, and carbohydrate (PFC) energy ratio, and lower panel shows relative intake of nutrients of general Japanese and citrin deficiency subjects. From [53]. 


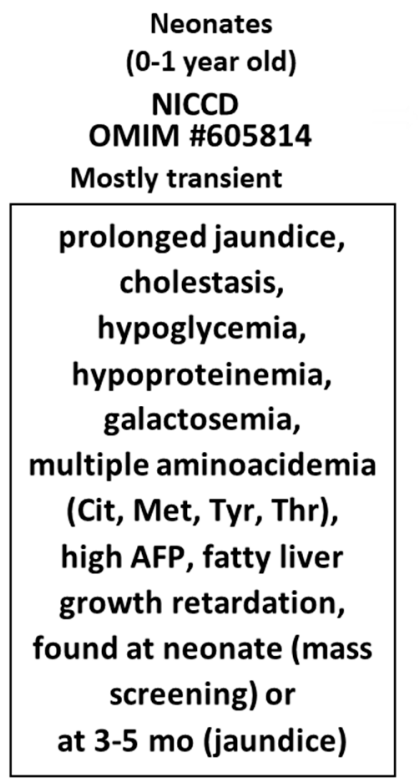

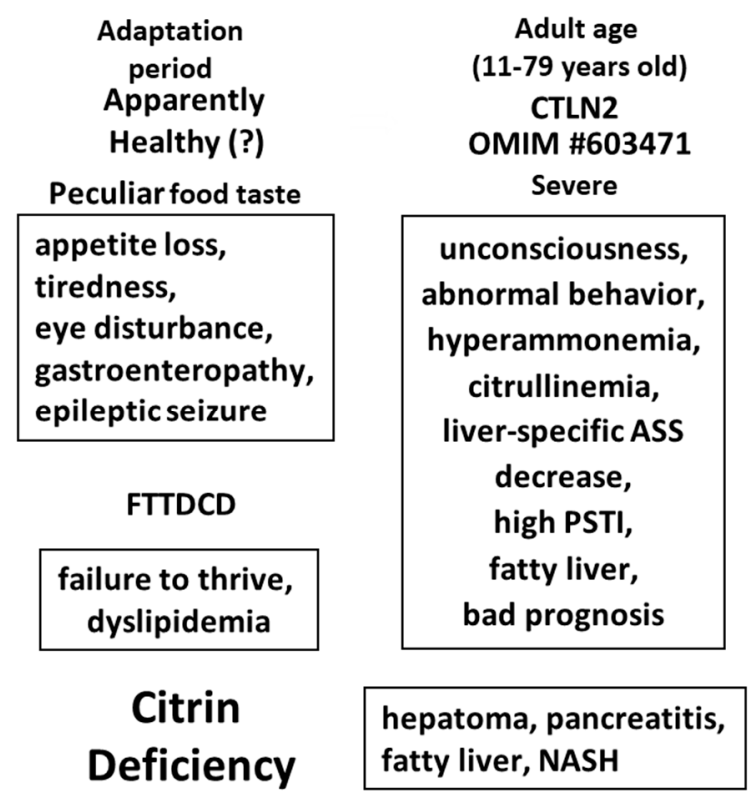

Figure 2. Relation between various disease types during lifetime in citrin deficiency. Modified from [55].

\section{The Metabolic Functions of Citrin and Disease Model}

The metabolic functions of citrin [56] were shown in Figure 3; (1) as a member of malate/Asp shuttle, it is important for transport of reducing equivalent of NADH into mitochondria which is related to production of ATP in the mitochondria; (2) it plays a role in transport of Asp from mitochondria to cytosol for synthesis of proteins, nucleotides, and urea; (3) it is indispensable for metabolism of lactate to glucose (gluconeogenesis) in order to avoid excess formation of NADH in the cytosol because of stoichiometry of NADH. Mutations of SLC25A13 gene disturb the metabolic functions listed above.

1. Supply of Asp to cytosol for syntheses of urea, proteins and nucleotides

2. Oxidation of cytosolic NADH reducing eq. for (1) aerobic glycolysis

(2) energy metabolism

3. Essential for gluconeogenesis from lactate due to stoichiometry of cytosolic NADH

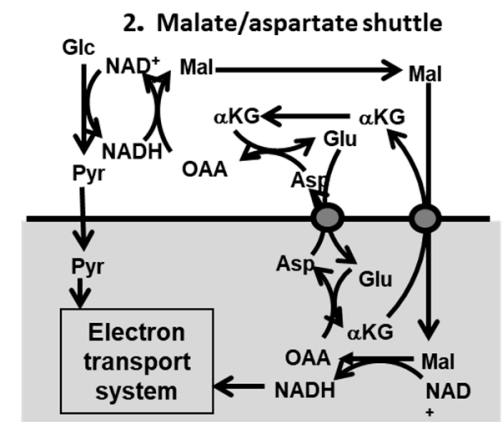

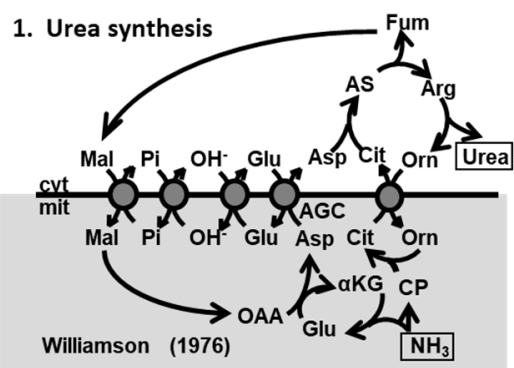

3. Gluconeogenesis from Lactate

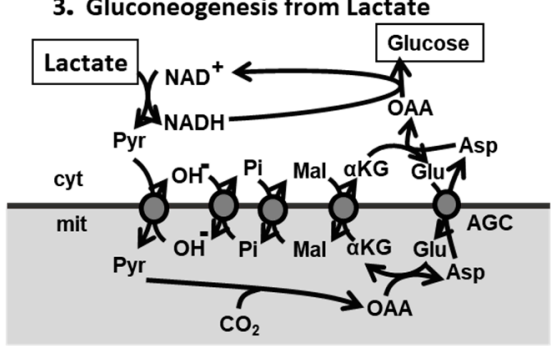

Figure 3. Metabolic functions of citrin. From [57].

We have created, at first, citrin gene knockout mice [58] as a model animal, which showed metabolic defects due to citrin-KO in vitro, but with almost no symptoms in vivo. The reason why the mice showed almost no symptoms, we postulated that the rodent liver contains another NADH shuttle, glycerophosphate shuttle, which compensates the defect of malate/Asp shuttle. So, we created 
double gene knockout mice, which lack not only SLC25A13, but also mitochondrial glycerol 3-phosphate dehydrogenase (Gpd2; mGPD), a member of glycerophosphate shuttle. The resultant citrin/mGPD double-KO mice recapitulated human citrin deficiency [59], showing hyperammonemia, citrullinemia, hypoglycemia, and growth retardation.

\section{Pathophysiology of the Double-KO Mice}

The double-KO mice showed hyperammonemia under fed conditions, but not under starved conditions [59] (Figure 4). Most characteristics is that the double-KO mice showed enhanced severe hyperammonemia when the mice were given sucrose solution forced per os (Figure 4). Furthermore, they did not like to take sucrose solution, as compared with other genotype mice including citrin-KO and mGPD-KO mice. We have shown that not only sucrose, but also, the components, both glucose and fructose [60], had the same effect, as shown in Figure 5. We propose that carbohydrate intake increases cytosolic NADH, which is the reason why citrin deficiency subjects dislike to take carbohydrates. Metabolomic analysis of the double-KO mice liver revealed six major metabolic abnormalities listed as follows [61], (1) a vast increase in glycerol 3-phosphate and ratio of G3P/dihydroxyacetonephosphate, (2) increased concentration of lysine caused by a decreased availability of $\alpha$-ketoglutarate, resulting in inhibition of breakdown of lysine, (3) increase of citrulline, (4) decreased concentration of Glu, (5) ATP, and (6) citrate. A marked increase in glycerol 3-phosphate (G3P), or G3P/dihyroxyacetone phosphate ratio indicates an increase in the $\mathrm{NADH} / \mathrm{NAD}{ }^{+}$ratio in the cytosolic compartment of the liver. This was caused by destruction of two NADH shuttles leading to accumulation of cytosolic NADH, which caused inhibition of glycolytic enzyme, glyceraldehyde 3-phosphate dehydrogenase. The increased NADH also suppressed oxaloacetate formation from malate and malate dehydrogenase, further formation of Asp by cytosolic Asp aminotransferase, together with defect of Asp supply from mitochondria [40], causing inhibition of ASS reaction, resulting in accumulation of citrulline and ammonia, and inhibition of urea synthesis. We postulate that decreased Glu comes from oxidation of $\mathrm{NADH}$ in the mitochondria by inactive malate/Asp shuttle and decreased TCA cycle activity, evidenced by low concentration of TCA cycle intermediates [59]. Decreased citrate comes from inhibition of glycolysis and cytosolic increase in $\mathrm{NADH} / \mathrm{NAD}^{+}$. ATP will decrease by inhibition of glycolysis and inactive malate/Asp shuttle.

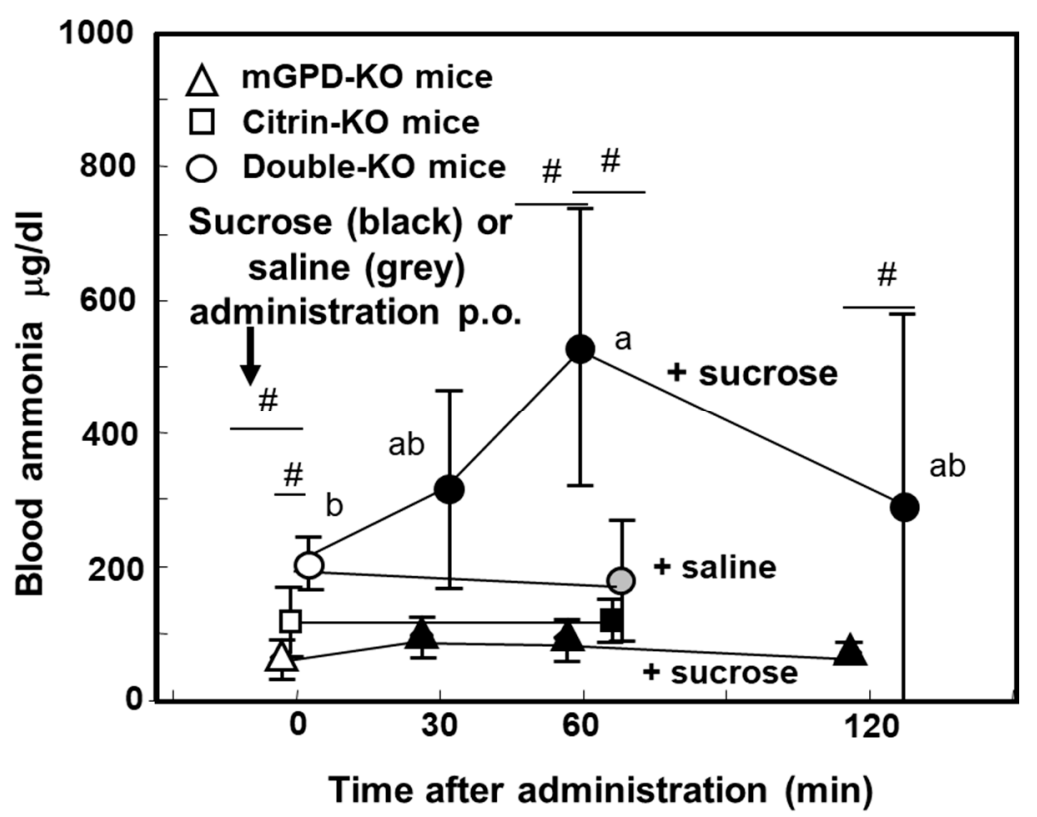

Figure 4. Effect of sucrose or $\mathrm{NaCl}$ administration on blood ammonia on fed mGPD-KO, citrin-KO, and double-KO mice. \# p $>0.05$ from value with Saline. Values with same character $(a, a b)$ indicate no statistical difference. From [57]. 

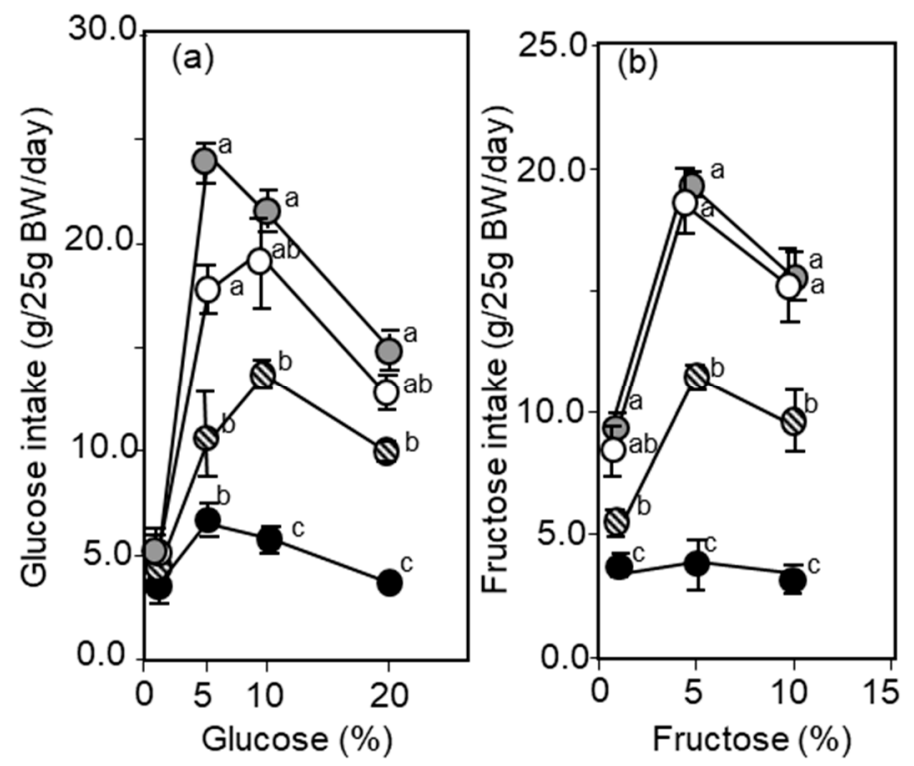

Figure 5. Voluntary intake of various concentrations of glucose (a) or fructose (b) and water (two bottles, water and a test solution) given to four kinds of mice, wild type (white circle), mGPD-KO (circle with stripes), citrin-KO (grey circle), and double-KO (black circle) were monitored. Concentrations are given in the figure. Intakes were compared statistically and differences were expressed with $a, b$, c. The same character indicates no difference. It is noteworthy that the double-KO mice took only a small amount of glucose and fructose solutions, as compared with other mice. From [59].

Voluntary intake test of sucrose, ethanol, and glycerol [60], of which intakes or administration caused onset or worsening of disease [1,62], revealed that the double-KO mice severely avoided the intakes, citrin-KO and mGPD-KO mice moderately avoided taking the higher concentration solutions of ethanol and glycerol. We found that high correlation between avoidance of intake of the solutions scored from the amounts of intake and comparison between the mice, and simultaneous hepatic increase in G3P and decrease in ATP [60]. We suggest that the two parameters, simultaneous increase in the NADH/NAD ${ }^{+}$ratio represented by the G3P concentration and decrease in ATP in the liver, send a signal to the brain to induce to suppress the intake of the solution or the foods which increase in hepatic cytosolic NADH and decrease in ATP. This consideration is important from a viewpoint of therapy of citrin deficiency. Namely, correction of either increased G3P or decreased ATP may stop the symptoms of citrin deficiency.

\section{Treatment of Citrin Deficiency Based on the Pathophysiology of the Disease}

Principle concept of citrin deficiency treatment should be based on the peculiar food intake tendency except that liver transplantation is the most effective in correcting all the metabolic disturbances [63,64], liver transplantation at early stage of the disease, almost all symptoms disappeared, suggesting that it is liver disease. Liver transplantation also normalizes the peculiar food taste (Kobayashi, unpublished data). Liver transplantation itself has some drawback, such as the cost and shortage in liver donors and not all the liver transplantation could help the lives of citrin deficiency patients probably due to immunological complications or other causes. Therefore, nutritional and medicinal therapeutic procedures are important. Basics of the therapy is nutrition. High carbohydrates diet causes anorexia in NICCD patients and hyperammonemia in CTLN2, so that low carbohydrates diet is important. High carbohydrates and low protein diet is the common therapeutic diet for liver diseases, which, however, was reported inappropriate [65]. Rather, carbohydrate-restricted diet or in addition high protein diet were found to be effective [2,66]. Infusion of high glucose solutions [67] or hyperosmotic solutions [62,68] for brain edema, such as Glyceol consisting of $10 \%$ glycerol and $5 \%$ fructose is contraindication. Infusion of high concentration of glucose caused hypermmonemia and consciousness 
disturbance to citrin deficiency patients [67]. You can use lower concentration (less than 10\%) of glucose, if the patients needed glucose. You may find many case reports listed in reference [62]; many case-report authors described that patients given Glyceol got irreversible deterioration and mostly died shortly after infusion of Glyceol [62].

On the other hand, we noticed that protein and some kinds of lipid in the diet may be effective for treatment. Nutritional assessment of a young girl with CTLN2 [69] disliked high carbohydrates diet and sweets, and she took her favorite diet which was rich in protein and lipid in spite of that with almost the same amount of carbohydrates as the high carbohydrate diet she took, suggesting an ameliorating effect of the other nutrients [70]. In the double-KO mice with component-defined diet, we showed that the high-carbohydrate diet (AIN-93, a diet for mature rodent recommended by American Institute for Nutrition in 1993) was strongly avoided by the double-KO mice, but addition of $8 \%$ protein (casein) by reducing carbohydrates by $8 \%$ caused appetite enough to recover the amount intake as usual with high protein laboratory chaw (CE2, a diet for rodent breeding supplied from CLEA Japan) [71], as shown in Figure 6. The casein was able to be replaced by single amino acid such as Ala and Glu. Furthermore, addition of 6\% MCT (medium-chain triglycerides) alone caused full intake as CE2, but none of triglycerides which consisted from long-chain fatty acids such as soybean oil, fish oil, and lard were effective, as shown in Table 2. It is because MCT is metabolized in the liver but not via tightly-regulated carnitine palmitoyltransferase I pathway.

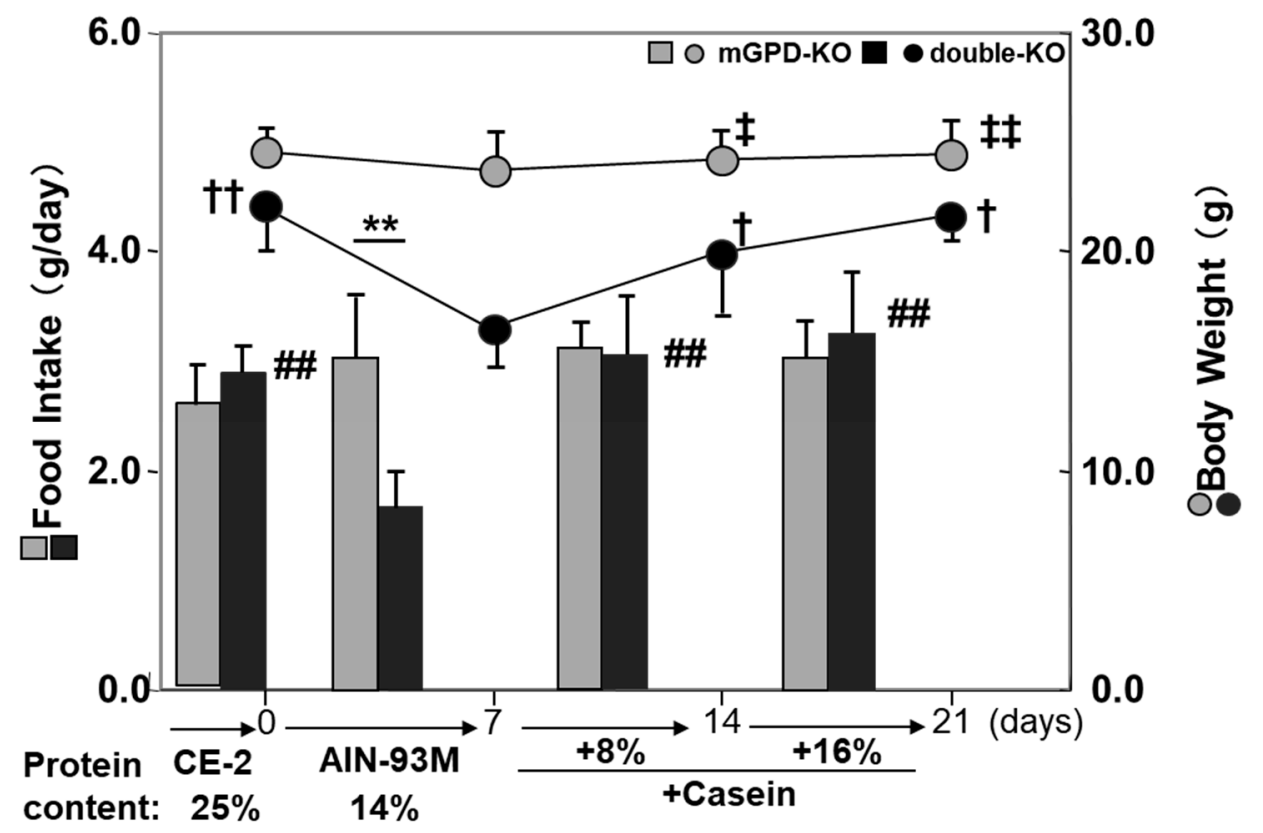

Figure 6. Intake of diet (high carbohydrate diet with defined composition, AIN-93M (recommended for mature rodent by American Institute for Nutrition in 1993) and body weight changes per week of mGPD-KO and double-KO mice and effect of supplementation of casein. The mice were usually given a high protein diet CE-2 (25\%) from Clea Japan and changed the diet to AIN-93M (protein content is $14 \%$ ), the intake is the average of a week and body weight changes in a week were monitored. Supplementation was done with reducing corn starch by the same amount. Differences in body weight

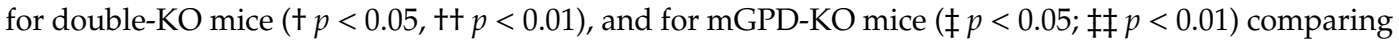
the AIN-93M diet versus other supplementation were determined using a paired t-tests. Difference in food intake between diets within each genotype were determined using paired t-tests (\# $p<0.01$; \#\# $p<$ $0.01)$ Difference in food intake between genotypes were determined using unpaired t-test (** $p<0.01)$ From [71]. 
Table 2. Effect of supplementation of protein, amino acids, and lipid on the food intake and body weight changes as shown in Figure 6. From [71].

\begin{tabular}{ccc}
\hline Change from CE-2 to & Body Weight & Food Intake \\
\hline AIN93M & Dec & Dec \\
\hline (Effect of supplements) & & \\
Protein ( $+8 \%)$ & Inc & Inc \\
Ala (5\%) & Inc & Inc \\
Na-Glu (5\%) & Inc & Inc \\
Na-Pyr (10\%) & Inc & Inc \\
MCT $(6 \%)$ & Inc & Inc \\
Soybean oil $(6 \%)$ & no & no \\
Lard $(6 \%)$ & no & no \\
Olive oil $(6 \%)$ & no & no \\
Fish oil $(6 \%)$ & no & no \\
\hline
\end{tabular}

Inc, increased; Dec, decreased; No indicates no change.

From the results, we searched for the most effective amino acid(s) [72]. Looking for amino acids which increase hepatic Asp, or decrease hepatic G3P level increased by administration of ethanol to citrin-KO mice [72]. Resultant candidate amino acids were glycine (Gly), Ala, ornithine (Orn), arginine (Arg), serine, Asp, and Glu. During this research, we also looked for amino acids which affect the hepatic citrulline level. Gly and serine were found to increase the hepatic citrulline level and furthermore, blood ammonia levels. According to this finding, we eliminated Gly and serine from the list. Furthermore, we were able to create a severe hyperammonemia model by administration of Gly and sucrose to the double-KO mice [72]. Using this model, we finally decided which amino acid(s) are the most effective. Figure 7a shows you the effect of various amino acids and MCT on decreasing blood ammonia increased by the addition of sucrose and Gly. The most effective were Orn+Asp or Orn+Ala; those decreased blood ammonia as low as wild type mice without Suc + Gly. Figure 7b shows plasma citrulline levels. Orn is well known to stimulate urea synthesis by increasing urea cycle capacity through increasing substrate level of OTC reaction, but increased plasma citrulline level as Arg (Figure 7b). Addition of Ala or Asp to Orn decreased the plasma citrulline level, indicating the action of these two amino acids are different from Orn and Arg. We postulated the acting point of Glu, Asp, and Ala are the same.

(a)

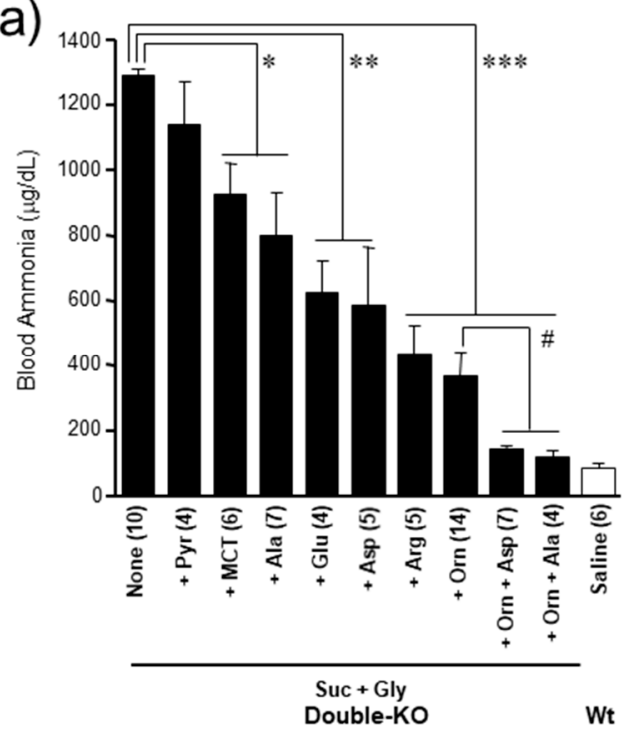

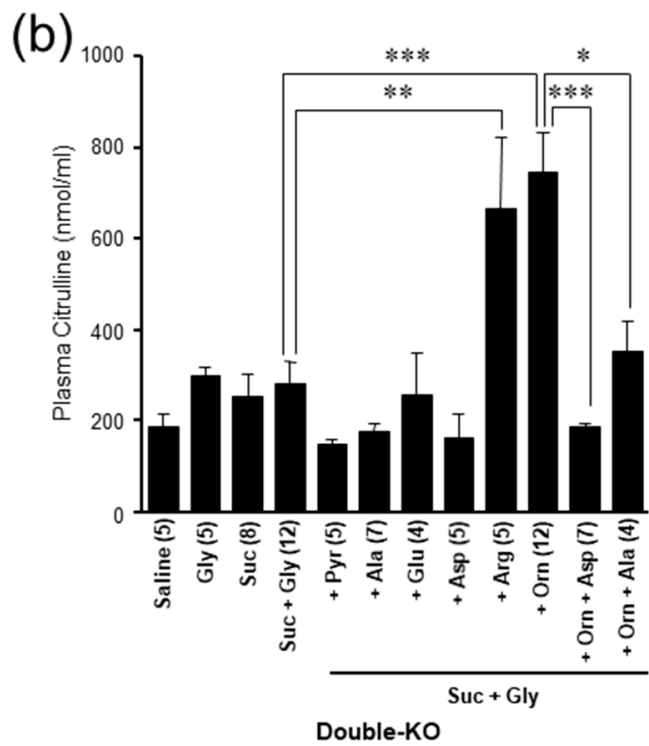

Figure 7. (a) Effects of enteral administration of $0.5 \mathrm{M}$ various amino acids, $0.5 \mathrm{M}$ sodium pyruvate, $5 \%$ MCT, or amino acid combination $(10 \mathrm{~mL} / \mathrm{kg} \mathrm{bw})$ on blood ammonia increased by administration of $20 \%$ 
sucrose +1 M Gly (20 mL/kg bw) in double-KO mice. (b) Effects of administration of amino acid and other substances indicated in the figure on plasma citrulline in the double-KO mice. Asterisks ${ }^{*} p<$ $\left.0.05 ;{ }^{* *} p<0.001 ;{ }^{* *} p<0.0001\right)$ denote statistical differences between indicated groups by unpaired t-test (Figure 7(a)) Asterisks ( ${ }^{*} p<0.05 ;{ }^{* *} p<0.001$; ${ }^{* * *} p<0.0001$ ) denote statistical differences vs saline. Values are shown with mean \pm standard error of mean. From [72].

On the other hand, we also tested Ala and Asp on ureagenesis in the perfused liver [72], as shown in Figure 8. The results show that Ala was effective in ureagenesis in any kinds of genotype mice including the double-KO mice but Asp was not at all effective. We have also reported the similar results with citrin-KO mice showing ineffectiveness of Asp [73]. This is accordant with the report by Stoll et al. [74] that Asp together with Glu and $\alpha$-ketoglutarate administered are transported into perivenous hepatocytes but not into periportal hepatocytes where the urea cycle enzymes are located. However, it is not consistent with our results showing effectiveness of Asp per os administered, as shown in Figure 7a.
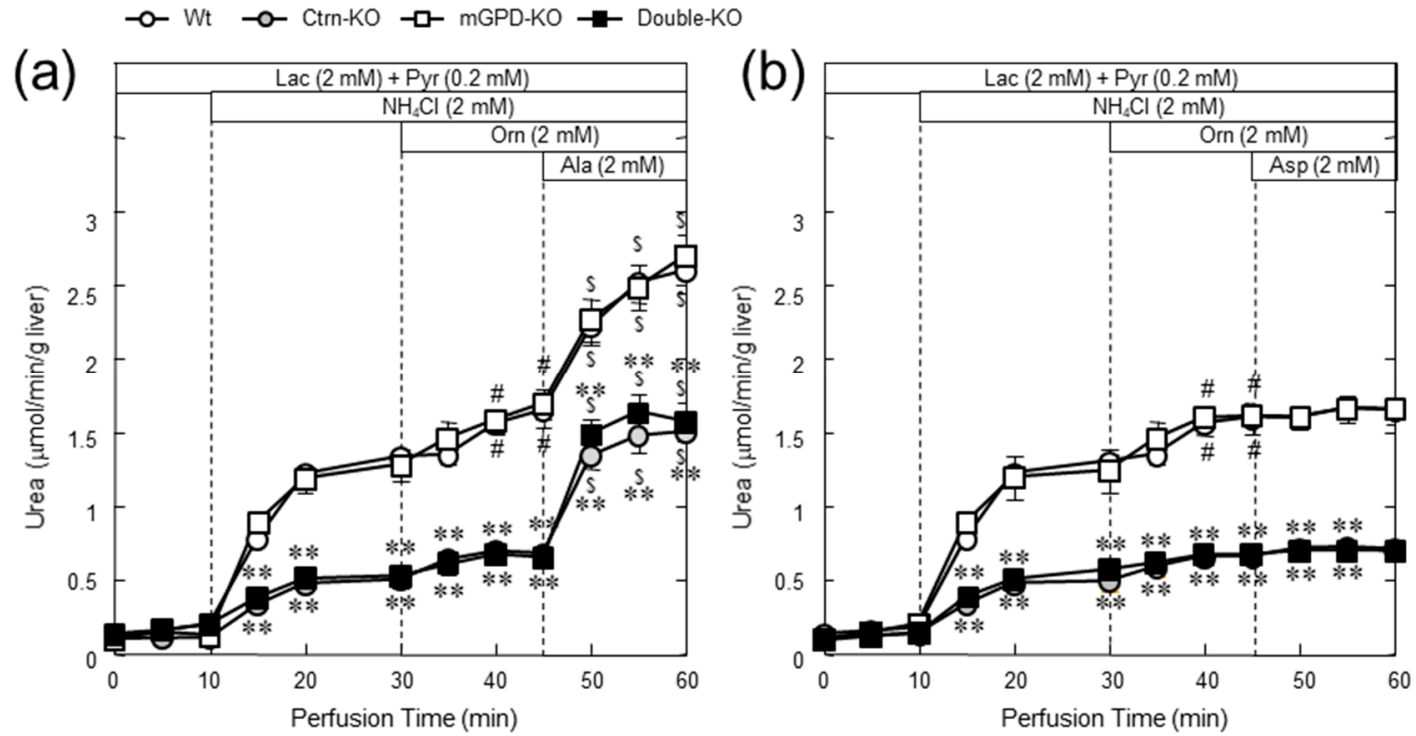

Figure 8. Ureagenesis from ammonium chloride in the perfused liver and effect of Ala (a) and Asp (b). In the upper part of the figures, the addition to the perfusion media is shown. Mice used are, wild type (white circle), citrin-KO (gray circle), mGPD-KO (white squire), and double-KO mice (black squire). * and ${ }^{* *}$ indicate statistical differences $(p<0.05$ and $p<0.01$, respectively) from wild type values and \# and $\$, p<0.05$ from the level at perfusion time 45 and $30 \mathrm{~min}$ within the same genotypes. From [72].

\section{Importance of Small Intestine on Metabolism of Amino Acids}

To solve this discrepancy, we considered the role of the small intestine in metabolism of amino acids. Actually, Neame and Wiseman [75], Parsons and Volman-Mitchell [76], and Windmueller and Spaeth [77] have shown that enterally-administered Asp is converted into Ala in the small intestine and then transported via the portal vein to the liver. In order to examine the role of the small intestine on the function of amino acids in the liver and confirm the results shown by the former researchers, we administered various amino acids enterally and assayed the concentrations of amino acids in the portal vein and abdominal aorta and calculated the difference in the amino acids between the two blood vessels. In our experiment, enteral administration of specific amino acids caused increases in each amino acid within the arterial circulation, and the clear portal-arterial difference, demonstrating an uptake of Gln and output of Ala, citrulline, and Pro (Figure 9). Our findings clearly demonstrate that some part of the Asp, Glu, and Orn were converted to Ala, but no significant conversion of Gly to Ala in the small intestine (Figure 9). It also suggests that the positive effect of Orn on enhancing ureagenesis appears to be more than simply increasing the urea-cycle intermediate levels. The results shown here suggest also that the Ala formed and supplied to the periportal hepatocytes can then be converted 
back to Asp by coupling of two cytosolic aminotransferases (Figure 10a,b), and the formed pyruvate can then oxidize malate to oxaloacetate, reinitiating ureagenesis under citrin deficiency (Figure 10b). Actually, the combination of Orn and Asp, L-ornithine L-aspartate (LOLA), which contains no $\mathrm{NaCl}$, was very effective in decreasing blood ammonia [72]. Acting site of Asp, analyzed by using crossover point analysis, clearly is an ASS step, as shown in Figure 11. This will be effective therapeutics for citrin deficiency. We are now examining LOLA as a clinical test.
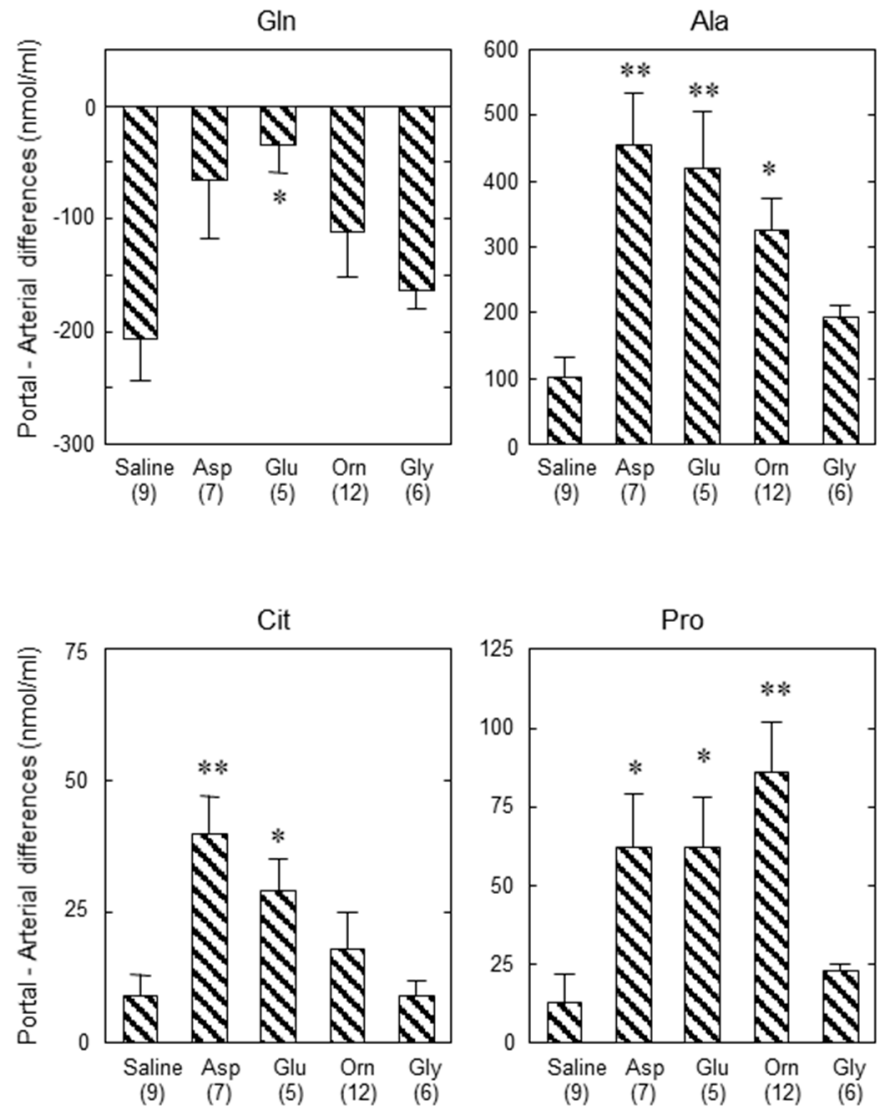

Figure 9. Portal vein-arterial differences in the plasma concentration of Gln, Ala, Cit, and Pro $1 \mathrm{~h}$ after administration of saline, Asp, Glu, Orn, or Gly. Plus values indicate output and minus values indicate uptake of the amino acid. Saline, Asp, Glu, Orn, or Gly $(20 \mathrm{~mL} / \mathrm{kg} \mathrm{bw} ; 10 \mathrm{mmol} / \mathrm{kg}$ bw) were enterally administered to $\mathrm{mGPD}-\mathrm{KO}$ mice and $1 \mathrm{~h}$ after the administration, blood was collected simultaneously from portal vein and abdominal aorta for portal vein-arterial difference. ${ }^{*} p<0.05$ and ${ }^{* *} p<0.001$ vs saline. From [70].

(a)

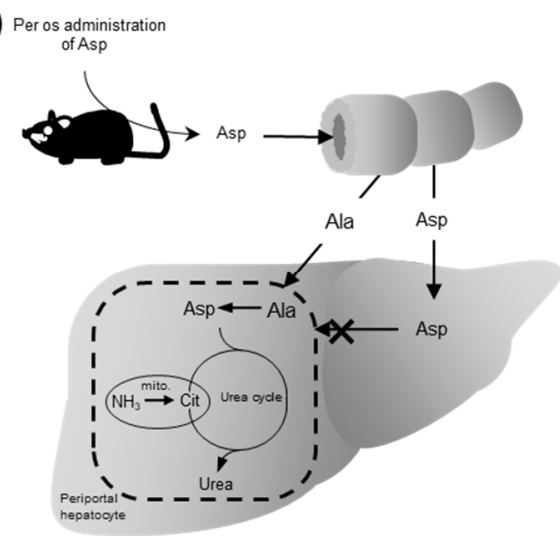

(b)

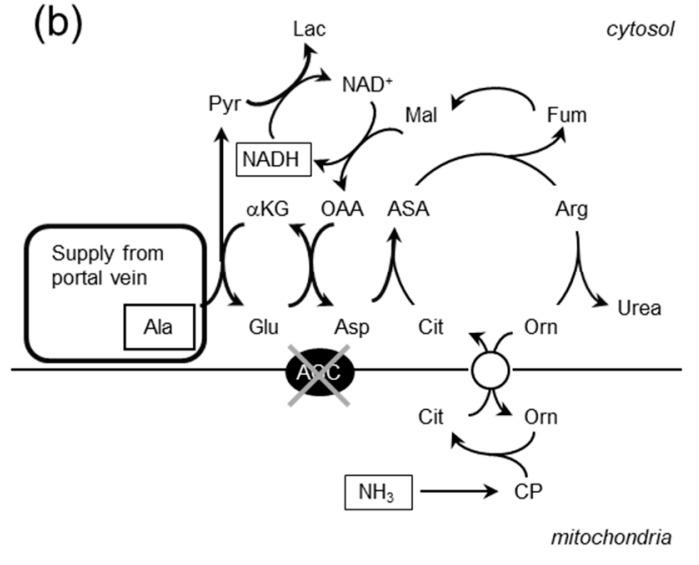

Figure 10. Schematic diagram of Asp metabolism after enteral administration within the small intestine (a) and liver (b) and postulated metabolic pathway of Ala in periportal hepatocytes. From [72]. 


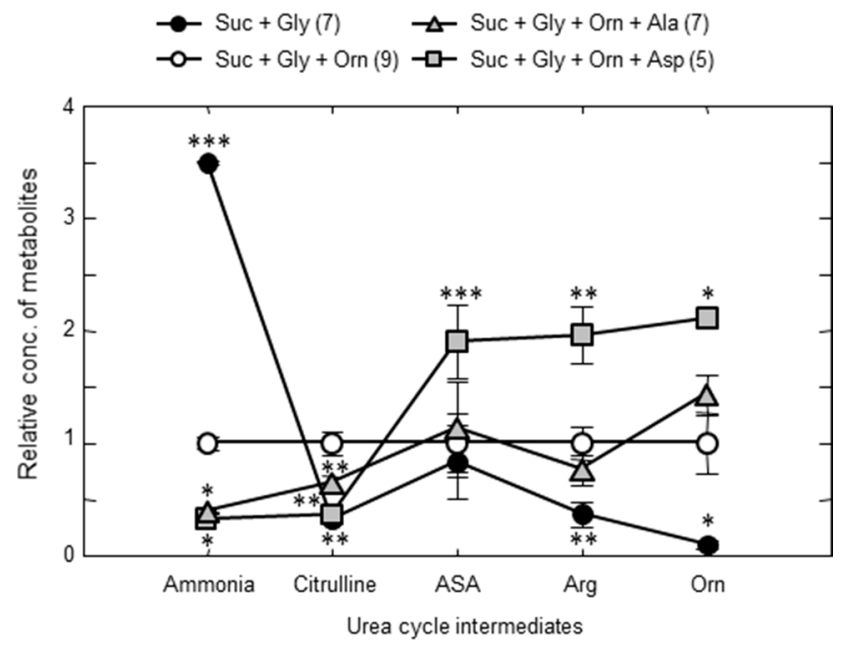

Figure 11. Crossover point analysis of Asp action. Each of hepatic and blood metabolite concentrations under Suc + Gly + Orn was set at 1 and the metabolite concentrations under the other conditions were calculated and plotted. The concentration of blood ammonia was used as ammonia in the figure. The line formed with Asp crossovered the basal line between citrulline and argininosuccinate, indicating that Asp activates ASS step. ${ }^{*} p<0.05 ;{ }^{* *} p<0.001$ and ${ }^{* * *} p<0.0001$ from the baseline of Suc + Gly + Orn. From [72].

\section{Drugs or Supplements Used as Therapeutics for Citrin Deficiency at Present}

L-Arginine: Arg was the first drug found effective in the blood ammonia decreasing drug by Hoshi et al. [78] and Imamura et al. [66]. It was effective at not only decreasing blood ammonia but also effective in decreasing plasma triglyceride [66].

Sodium Pyruvate: Sodium pyruvate was used to consume glycolytic NADH by producing lactate, and then decreasing blood ammonia probably by producing oxaloacetate and aspartate. It was found effective in controlling the pathogenic state of citrin deficiency by Moriyama et al. [73], clinically by Mutoh et al. [69] and Yazaki et al. [79].

MCT: MCT was originally used as an energy supply for various metabolic diseases including NICCD [80]. Hayasaka et al. [81] successfully used MCT for the treatment of CTLN2. They emphasize $\mathrm{MCT}$ as the energy source for the liver. But the mechanism of action is not clear yet. Saheki et al. [71] used MCT in the treatment of model mice, and Saheki et al. [82] and Moriyama et al. [83] analyzed the mechanism of action of MCT, the latter using the perfused liver system. Both agreed MCT increased synthesis of Gln. How does Gln, which is not the end product, but an intermediate metabolite of nitrogen metabolism work? Therefore, how Gln works by further metabolism is the next question.

All these clinical tests propose effectiveness of Arg, sodium pyruvate, and MCT in treatment of citrin deficiency. Further extensive clinical trials of these candidates including LOLA are needed.

Funding: This study was supported by KAKENHI, Grants from Ministry of Health, Labor and Welfare of Japan and Grants for Research for Promoting Technological seeds from Japan Science and Technology Agency. Recent several years, this study was greatly supported by Citrin Foundation established by Barbara Yu Fa and Yen How Tai in Singapore.

Acknowledgments: This study was done in collaboration with many collaborators including clinical doctors, patients and their families. The most important researcher in this study is late Keiko Kobayashi who discovered the causative gene for CTLN2 and passed away in 2010. I only list major collaborators who worked with Saheki at Kagoshima University, Tokushima Bunri University and Kumamoto University, Yasushi Imamura, Izumi Yasuda, Yoshiko Setogawa, Qinghua Gao, Miharu Ushikai, Kanako Inoue, and Sumie Furuie. I also thank, Late Nobuhiko Katunuma, Ken-ichi Yamamura, Tatsuhiko Furukawa, and Masahisa Horiuchi, who gave me opportunities to study by providing laboratories and equipments after my retirement at Tokushima Bunri University, Kumamoto University and Kagoshima University, respectively.

Conflicts of Interest: The authors declare no conflict of interest. 


\section{References}

1. Saheki, T.; Song, Y.Z. Citrin Deficiency; Adam, M.P., Ardinger, H.H., Pagon, R.A., Wallace, S.E., Bean, L.J.H., Stephens, K., Amemiya, A., Eds.; University of Washington: Seattle, WA, USA, 1993.

2. Dimmock, D.; Kobayashi, K.; Iijima, M.; Tabata, A.; Wong, L.J.; Saheki, T.; Lee, B.; Scaglia, F. Citrin deficiency: A novel cause of failure to thrive that responds to a high-protein, low-carbohydrate diet. Pediatrics 2007, 119, e773-e777. [CrossRef] [PubMed]

3. Yasuda, T.; Yamaguchi, N.; Kobayashi, K.; Nishi, I.; Horinouchi, H.; Jalil, M.A.; Li, M.X.; Ushikai, M.; Iijima, M.; Kondo, I.; et al. Identification of two novel mutations in the SLC25A13 gene and detection of seven mutations in 102 patients with adult-onset type II citrullinemia. Hum. Genet. 2000, 107, 537-545. [CrossRef] [PubMed]

4. Yamaguchi, N.; Kobayashi, K.; Yasuda, T.; Nishi, I.; Iijima, M.; Nakagawa, M.; Osame, M.; Kondo, I.; Saheki, T. Screening of SLC25A13 mutations in early and late onset patients with citrin deficiency and in the Japanese population: Identification of two novel mutations and establishment of multiple DNA diagnosis methods for nine mutations. Hum. Mutat. 2002, 19, 122-130. [CrossRef] [PubMed]

5. Hwu, W.L.; Kobayashi, K.; Hu, Y.H.; Yamaguchi, N.; Saheki, T.; Chou, S.P.; Wan, J.H. A Chinese adult onset type II citrullinaemia patient with 851del4/1638ins23 mutations in the SLC25A13 Gene. J. Med. Genet. 2001, 38, E23. [CrossRef] [PubMed]

6. Ko, J.M.; Kim, G.H.; Kim, J.H.; Kim, J.Y.; Choi, J.H.; Ushikai, M.; Saheki, T.; Kobayashi, K.; Yoo, H.W. Six cases of citrin deficiency in Korea. Int. J. Mol. Med. 2007, 20, 809-815. [CrossRef]

7. Song, Y.Z.; Li, B.X.; Chen, F.P.; Liu, S.R.; Sheng, J.S.; Ushikai, M.; Zhang, C.H.; Zhang, T.; Wang, Z.N.; Kobayashi, K.; et al. Neonatal intrahepatic cholestasis caused by citrin deficiency: Clinical and laboratory investigation of 13 subjects in mainland of China. Dig. Liver Dis. 2009, 41, 683-689. [CrossRef]

8. Hutchin, T.; Preece, M.A.; Hendriksz, C.; Chakrapani, A.; McClelland, V.; Okumura, F.; Song, Y.Z.; Iijima, M.; Kobayashi, K.; Saheki, T.; et al. Neonatal Intrahepatic Cholestasis Caused by Citrin Deficiency (NICCD) as a Cause of Liver Disease in Infants in the UK. J. Inherit. Metab. Dis. 2009, 32, S151-S155. [CrossRef]

9. Fiermonte, G.; Parisi, G.; Martinelli, D.; De Leonardis, F.; Torre, G.; Pierri, C.L.; Saccari, A.; Lasorsa, F.M.; Vozza, A.; Palmieri, F.; et al. A new Caucasian case of neonatal intrahepatic cholestasis caused by citrin deficiency (NICCD): A clinical, molecular, and functional study. Mol. Genet. Metab. 2011, 104, 501-506. [CrossRef]

10. Palmieri, F. The mitochondrial transporter family SLC25; Identification, properties and physiopathology. Mol. Aspects Med. 2013, 34, 465-484. [CrossRef]

11. Palmieri, F.; Scarcia, P.; Monne, M. Diseases caused by mutations in mitochondrial carrier genes SLC25: A review. Biomolecules 2020, 10, 655. [CrossRef]

12. Lu, Y.B.; Kobayashi, K.; Ushikai, M.; Tabata, A.; Iijima, M.; Li, M.X.; Lei, L.; Kawabe, K.; Taura, S.; Yang, Y.; et al. Frequency and Distribution in East Asia of 12 Mutations Identified in the SLC25A13 Gene of Japanese Patients With Citrin Deficiency. J. Hum. Genet. 2005, 50, 338-346. [CrossRef] [PubMed]

13. Kikuchi, A.; Arai-Ichinoi, N.; Sakamoto, O.; Matsubara, Y.; Saheki, T.; Kobayashi, K.; Ohura, T.; Kure, S. Simple and Rapid Genetic Testing for Citrin Deficiency by Screening 11 Prevalent Mutations in SLC25A13. Mol. Genet. Metab. 2012, 105, 553-558. [CrossRef]

14. Saheki, T.; Kobayashi, K. Mitochondrial aspartate glutamate carrier (citrin) deficiency as the cause of adult-onset type II citrullinemia (CTLN2) and idiopathic neonatal hepatitis (NICCD). J. Hum. Genet. 2002, 47, 333-341. [CrossRef] [PubMed]

15. Tazawa, Y.; Kobayashi, K.; Ohura, T.; Abukawa, D.; Nishinomiya, F.; Hosoda, Y.; Yamashita, M.; Nagata, I.; Kono, Y.; Yasuda, T.; et al. Infantile cholestatic jaundice associated with adult-onset type II citrullinemia. J. Pediatr. 2001, 138, 735-740. [CrossRef] [PubMed]

16. Ohura, T.; Kobayashi, K.; Tazawa, Y.; Nishi, I.; Abukawa, D.; Sakamoto, O.; Iinuma, K.; Saheki, T. Neonatal presentation of adult-onset type II citrullinemia. Hum. Genet. 2001, 108, 87-90. [CrossRef] [PubMed]

17. Tomomasa, T.; Kobayashi, K.; Kaneko, H.; Shimura, H.; Fukusato, T.; Tabata, M.; Inoue, Y.; Ohwada, S.; Kasahara, M.; Morishita, Y.; et al. Possible clinical and histologic manifestations of adult-onset type II citrullinemia in early infancy. J. Pediatr. 2001, 138, 741-743. [CrossRef]

18. Song, Y.Z.; Guo, L.; Yang, Y.L.; Han, L.S.; Kobayashi, K.; Saheki, T. Failure to thrive and dyslipidemia caused by citrin deficiency: A novel clinical phenotype. Chin. J. Contemp. Pediatrics 2009, 11, 328-332. 
19. Ikeda, S.; Kawa, S.; Takei, Y.; Yamamoto, K.; Shimojo, H.; Tabata, K.; Kobayashi, K.; Saheki, T. Chronic pancreatitis associated with adult-onset type II citrullinemia: Clinical and pathologic findings. Ann. Intern. Med. 2004, 141, W109-W110. [CrossRef]

20. Komatsu, M.; Yazaki, M.; Tanaka, N.; Sano, K.; Hashimoto, E.; Takei, Y.; Song, Y.Z.; Tanaka, E.; Kiyosawa, K.; Saheki, T.; et al. Citrin deficiency as a cause of chronic liver disorder mimicking non-alcoholic fatty liver disease. J. Hepatol. 2008, 49, 810-820. [CrossRef]

21. Lee, B.H.; Jin, H.Y.; Kim, G.H.; Choi, J.H.; Yoo, H.W. Nonalcoholic fatty liver disease in 2 siblings with adult-onset type II citrullinemia. J. Pediatr. Gastroenterol. Nutr. 2010, 50, 682-685. [CrossRef]

22. Soeda, J.; Yazaki, M.; Nakata, T.; Miwa, S.; Ikeda, S.; Hosoda, W.; Iijima, M.; Kobayashi, K.; Saheki, T.; Kojiro, M.; et al. Primary liver carcinoma exhibiting dual hepatocellular-biliary epithelial differentiations associated with citrin deficiency: A case report. J. Clin. Gastroenterol. 2008, 42, 855-860. [CrossRef] [PubMed]

23. Hagiwara, N.; Sekijima, Y.; Takei, Y.; Ikeda, S.; Kawasaki, S.; Kobayashi, K.; Saheki, T. Hepatocellular carcinoma in a case of adult-onset type II citrullinemia. Inter. Med. 2003, 42, 978-982. [CrossRef]

24. Saheki, T.; Sase, M.; Nakano, K.; Azuma, F.; Katsunuma, T. Some properties of argininosuccinate synthetase purified from human liver and a comparison with the rat liver enzyme. J. Biochem. 1983, 93, 1531-1537. [CrossRef] [PubMed]

25. Saheki, T.; Ueda, A.; Hosoya, M.; Kusumi, K.; Takada, S.; Tsuda, M.; Katsunuma, T. Qualitative and quantitative abnormalities of argininosuccinate synthetase in citrullinemia. Clin. Chim. Acta 1981, 109, 325-335. [CrossRef]

26. Saheki, T.; Ueda, A.; Iizima, K.; Yamada, N.; Kobayashi, K.; Takahashi, K.; Katsunuma, T. Argininosuccinate synthetase activity in cultured skin fibroblasts of citrullinemic patients. Clin. Chim. Acta 1982, 118, 93-97. [PubMed]

27. Kobayashi, K.; Jackson, M.J.; Tick, D.B.; O’Brien, W.E.; Beaudet, A.L. Heterogeneity of mutations in argininosuccinate synthetase causing human citrullinemia. J. Biol. Chem. 1990, 265, 11361-11367. [PubMed]

28. Saheki, T.; Kobayashi, K.; Inoue, I.; Matuo, S.; Hagihara, S.; Noda, T. Increased urinary excretion of argininosuccinate in type II citrullinemia. Clin. Chim. Acta 1987, 170, 297-304. [CrossRef]

29. Kobayashi, K.; Horiuchi, M.; Saheki, T. Pancreatic secretory trypsin inhibitor as a diagnostic marker for adult-onset type II citrullinemia. Hepatology 1997, 25, 1160-1165. [CrossRef]

30. Kobayashi, K.; Nakata, M.; Terazono, H.; Shinsato, T.; Saheki, T. Pancreatic secretory trypsin inhibitor gene is highly expressed in the liver of adult-onset type II citrullinemia. FEBS Lett. 1995, 372, 69-73. [CrossRef]

31. Tsuboi, H.; Fijino, Y.; Kobayashi, K.; Saheki, T.; Yamada, T. High serum pancreatic secretory trypsin inhibitor before onset of type II citrullinemia. Neurology 2001, 57, 933. [CrossRef]

32. Kobayashi, K.; Shaheen, N.; Terazono, H.; Saheki, T. Mutations in argininosuccinate synthetase mRNA of Japanese patients, causing classical citrullinemia. Am. J. Hum. Genet. 1994, 53, 1103-1112.

33. Kakinoki, H.; Kobayashi, K.; Terazono, H.; Nagata, Y.; Saheki, T. Mutations and DNA diagnoses of classical citrullienemia. Hum. Mutat. 1997, 9, 250-259. [CrossRef]

34. Kobayashi, K.; Kakinoki, H.; Fukushige, T.; Shaheen, N.; Terazono, H.; Saheki, T. Nature and frequency of mutations in the argininosuccinate synthetase gene that cause classical citrullinemia. Hum. Genet. 1995, 96, 454-463. [CrossRef] [PubMed]

35. Kobayashi, K.; Shaheen, N.; Kumashiro, R.; Tanikawa, K.; O’Brien, W.E.; Beaudet, A.L.; Saheki, T. A search for the primary abnormality in adult-onset type II citrullinemia. Am. J. Hum. Genet. 1993, 53, 1024-1030. [PubMed]

36. Sase, M.; Kobayashi, K.; Imamura, Y.; Saheki, T.; Nakano, K.; Miura, S.; Mori, M. Levels of translatable messenger RNA coding for argininosuccinate synthetase in the liver of the patients with quantitative-type citrullinemia. Hum. Genet. 1985, 69, 130-134. [CrossRef]

37. Kobayashi, K.; Saheki, T.; Imamura, Y.; Noda, T.; Inoue, I.; Matuo, S.; Hagihara, S.; Nomiyama, H.; Jinno, Y.; Shimada, K. Messenger RNA coding for argininosuccinate synthetase in citrullinemia. Am. J. Hum. Genet. 1986, 38, 667-680.

38. Kobayashi, K.; Sinasac, D.S.; Iijima, M.; Boright, A.P.; Begum, L.; Lee, J.R.; Yasuda, T.; Ikeda, S.; Hirano, R.; Terazono, H.; et al. The gene mutated in adult-onset type II citrullinaemia encodes a putative mitochondrial carrier protein. Nat. Genet. 1999, 22, 159-163. [CrossRef] 
39. del Arco, A.; Satrústegui, J. Molecular cloning of Aralar, a new member of the mitochondrial carrier superfamily that binds calcium and is present in human muscle and brain. J. Biol. Chem. 1998, 273, 23327-23334. [CrossRef]

40. Palmieri, L.; Pardo, B.; Lasorsa, F.M.; del Arco, A.; Kobayashi, K.; Iijima, M.; Runswick, M.J.; Walker, J.E.; Saheki, T.; Satrústegui, J.; et al. Citrin and aralar1 are $\mathrm{Ca}(2+)$-stimulated aspartate/glutamate transporters in mitochondria. EMBO J. 2001, 20, 5060-5069. [CrossRef]

41. Lasorsa, F.M.; Pinton, P.; Palmieri, L.; Fiermonte, G.; Rizzuto, R.; Palmieri, F. Recombinant expression of the $\mathrm{Ca}(2+)$-sensitive aspartate/glutamate carrier increases mitochondrial ATP production in agonist-stimulated Chines hamster ovary cells. J. Biol. Chem. 2003, 378, 38685-38692.

42. Begum, L.; Jalil, M.A.; Kobayashi, K.; Iijima, M.; Li, M.X.; Yasuda, T.; Horiuchi, M.; del Arco, A.; Satrústegui, J.; Saheki, T. Expression of three mitochondrial solute carriers, citrin, aralar1 and ornithine transporter, in relation to urea cycle in mice. Biochim. Biophys. Acta 2002, 1574, 283-292. [CrossRef]

43. Amoedo, N.D.; Punzi, G.; Obre, E.; Lacombe, D.; De Grassi, A.; Pierri, C.L.; Rossignol, R. AGC1/2, the mitochondrial aspartate-glutamate carriers. Biochim. Biophys. Acta 2016, 1863, 2394-2412. [CrossRef] [PubMed]

44. Wibom, R.; Lasorsa, F.M.; Töhönen, V.; Barbaro, M.; Sterky, F.H.; Kucinski, T.; Naess, K.; Jonsson, M.; Pierri, C.L.; Palmieri, F.; et al. AGC1 deficiency associated with global cerebral hypomyelination. N. Engl. J. Med. 2009, 361, 489-495. [CrossRef] [PubMed]

45. Falk, M.J.; Li, D.; Gai, X.; McCormick, E.; Place, E.; Lasorsa, F.M.; Otieno, F.G.; Hou, C.; Kim, C.E.; Abdel-Magid, N.; et al. AGC1 deficiency causes infantile epilepsy, abnormal myelination, and reduced N-acetylaspartate. JIMD Rep. 2014, 14, 77-85. [PubMed]

46. Ohura, T.; Kobayashi, K.; Tazawa, Y.; Abukawa, D.; Sakamoto, O.; Tsuchiya, S.; Saheki, T. Clinical pictures of 75 patients with neonatal intrahepatic cholestasis caused by citrin deficiency (NICCD). J. Inherit. Metab. Dis. 2007, 30, 139-144. [CrossRef] [PubMed]

47. Kobayashi, K.; Lu, Y.B.; Li, M.X.; Nishi, I.; Hsiao, K.j.; Choeh, K.; Yang, Y.L.; Hwu, W.L.; Reinhardt, J.K.V.; Palmieri, F.; et al. Screening of nine SLC25A13 mutations: Their frequency in patients with citrin deficiency and high carrier rates in Asian populations. Mol. Genet. Metab. 2003, 80, 356-359. [CrossRef]

48. Ben-Shalom, E.; Kobayashi, K.; Shaag, A.; Yasuda, T.; Gao, H.Z.; Saheki, T.; Bachmann, C.; Elpeleg, O. Infantile citrullinemia caused by citrin deficiency with increased dibasic amino acids. Mol. Genet. Metab. 2002, 77, 202-208. [CrossRef]

49. Naito, E.; Ito, M.; Matsuura, S.; Yokoto, I.; Saijo, T.; Ogura, Y.; Kitamura, S.; Kobayashi, K.; Saheki, T.; Nishimura, Y.; et al. Type II citrullinemia (citrin deficiency) in a neonate with hypergalactosemia detected by mass screening. J. Inherit. Meta. Dis. 2002, 25, 71-76. [CrossRef]

50. Ohura, T.; Kobayashi, K.; Abukawa, D.; Tazawa, Y.; Akikawa, J.; Sakamoto, O.; Saheki, T.; Iinuma, K. A novel inborn error of metabolism detected by elevated methionine and/or galactose in newborn screening: Neonatal intrahepatic cholestasis caused by citrin deficiency. Eur. J. Pediatr. 2003, 162, 317-322. [CrossRef]

51. Tamamori, A.; Okano, Y.; Ozaki, H.; Fujimoto, A.; Kajiwara, M.; Fukuda, K.; Kobayashi, K.; Saheki, T.; Tagami, Y.; Yamano, T. Neonatal intrahepatic cholestasis caused by citrin deficiency: Severe hepatic dysfunction in an infant requiring liver transplantation. Eur. J. Pediatr. 2002, 161, 609-613. [CrossRef]

52. Okano, Y.; Kobayashi, K.; Ihara, K.; Ito, T.; Yoshino, M.; Watanabe, Y.; Kaji, S.; Ohura, T.; Nagao, M.; Noguchi, A.; et al. Fatigue and quality of life in citrin deficiency during adaptation and compensation stage. Mol. Genet. Metab. 2013, 109, 9-13. [CrossRef] [PubMed]

53. Saheki, T.; Kobayashi, K.; Terashi, M.; Ohura, T.; Yanagawa, Y.; Okano, Y.; Hattori, T.; Fujimoto, H.; Mutoh, K.; Kizaki, Z.; et al. Reduced carbohydrate intake in citrin-deficient subjects. J. Inherit. Metab. Dis. 2008, 31, 386-394. [CrossRef] [PubMed]

54. Nakamura, M.; Yazaki, M.; Kobayashi, Y.; Fukushima, K.; Ikeda, S.; Kobayashi, K.; Saheki, T.; Nakaya, Y. The characteristics of food intake in patients with type II citrullinemia. J. Nutr. Sci. Vitaminol. 2011, 57, $239-245$. [CrossRef]

55. Saheki, T.; Kobayashi, K. Physiological role of citrin, a liver-type mitochondrial aspartate-glutamate carrier, and pathophysiology of citrin deficiency. Recent Res. Devel. Life Sci. 2005, 3, 59-73.

56. Saheki, T.; Kobayashi, K.; Iijima, M.; Horiuchi, M.; Begum, L.; Jalil, M.A.; Li, M.X.; Lu, Y.B.; Ushikai, M.; Tabata, A.; et al. Adult-onset type II citrullinemia and idiopathic neonatal hepatitis caused by citrin 
deficiency: Involvement of the aspartate glutamate carrier for urea synthesis and maintenance of the urea cycle. Mol. Genet. Metab. 2004, 81, S20-S26. [CrossRef] [PubMed]

57. Saheki, T. What is the function of citrin? In Citrin Deficiency-A Unique Disease that Many Doctors Don't Know; Fueisha: Osaka, Japan, 2017; pp. 53-58.

58. Sinasac, D.S.; Moriyama, M.; Jalil, M.A.; Begum, L.; Li, M.X.; Iijima, M.; Horiuchi, M.; Robinson, B.H.; Kobayashi, K.; Saheki, T.; et al. Slc25a13-knockout mice harbor metabolic deficits but fail to display hallmarks of adult-onset type II citrullinemia. Mol. Cell. Biol. 2004, 24, 527-536. [CrossRef] [PubMed]

59. Saheki, T.; Iijima, M.; Li, M.X.; Kobayashi, K.; Horiuchi, M.; Ushikai, M.; Okumura, F.; Meng, X.J.; Inoue, I.; Tajima, A.; et al. Citrin/mitochondrial glycerol-3-phosphate dehydrogenase double-knockout mice recapitulate features of human citrin deficiency. J. Biol. Chem. 2007, 282, 25041-25052. [CrossRef] [PubMed]

60. Saheki, T.; Inoue, K.; Ono, H.; Fujimoto, Y.; Furuie, S.; Yamamura, K.; Kuroda, E.; Ushikai, M.; Asakawa, A.; Inui, A.; et al. Oral aversion to dietary sugar, ethanol and glycerol correlates with alterations in specific hepatic metabolites in a mouse model of human citrin deficiency. Mol. Genet. Metab. 2017, 120, 306-316. [CrossRef]

61. Saheki, T.; Inoue, K.; Ono, H.; Tushima, A.; Katsura, N.; Yokogawa, M.; Yoshidumi, Y.; Kuhara, T.; Ohse, M.; Eto, K.; et al. Metabolomic analysis reveals hepatic metabolite perturbations in citrin/mitochondrial glycerol-3-phosphate dehydrogenase double-knockout mice, a model of human citrin deficiency. Mol. Genet. Metab. 2011, 104, 492-500. [CrossRef]

62. Yazaki, M.; Takei, Y.; Kobayashi, K.; Saheki, T.; Ikeda, S. Risk of worsened encephalopathy after intravenous glycerol therapy in patients with adult-onset type II citrullinemia (CTLN2). Intern. Med. 2005, 44, 188-195. [CrossRef]

63. Todo, S.; Starzel, T.E.; Tzakis, A.; Benkov, K.J.; Kalousek, F.; Saheki, T.; Tanikawa, K.; Fenton, W.A. Orthotopic liver transplantation for urea cycle enzyme deficiency. Hepatology 1992, 15, 419-422. [CrossRef] [PubMed]

64. Ikeda, S.; Yazaki, M.; Takei, Y.; Ikegami, T.; Hashikura, Y.; Kawasaki, S.; Iwai, M.; Kobayashi, K.; Saheki, T. Type II (adult onset) citrullinaemia: Clinical pictures and the therapeutic effect of liver transplantation. J. Neurol. Neurosurg. Psychiatry 2001, 71, 663-670. [CrossRef] [PubMed]

65. Fukushima, K.; Yazaki, M.; Nakamura, M.; Tanaka, N.; Kobayashi, K.; Saheki, T.; Takei, H.; Ikeda, S. Conventional diet therapy for hyperammonemia is risky in the treatment of hepatic encephalopathy associated with citrin deficiency. Intern. Med. 2010, 49, 243-247. [CrossRef] [PubMed]

66. Imamura, Y.; Kobayashi, K.; Shibatou, T.; Aburada, S.; Tahara, K.; Kubozono, O.; Saheki, T. Effectiveness of carbohydrate-restricted diet and arginine granules therapy for adult-onset type II citrullinemia: A case report of siblings showing homozygous SLC25A13 mutation with and without the disease. Hepatol. Res. 2003, 26, 68-72. [CrossRef]

67. Tamakawa, S.; Nakamura, H.; Katano, T.; Yoshizawa, M.; Ohtake, K.; Kubota, T. Hyperalimentation therapy produces a comatose state in a patient with citrullinemia. J. Jpn. Soc. Intensive. Care. Med. 1994, 1, 37-41. [CrossRef]

68. Takahashi, H.; Kagawa, T.; Kobayashi, K.; Hirabayashi, H.; Yui, M.; Begum, L.; Mine, T.; Takagi, S.; Saheki, T.; Shinohara, Y. A Case of adult-onset type ii citrullinemia-Deterioration of clinical course after infusion of hyperosmotic and high sugar solutions. Med. Sci. Monit. 2006, 12, CS13-CS15. [PubMed]

69. Mutoh, K.; Kurokawa, K.; Kobayashi, K.; Saheki, T. Treatment of a citrin-deficient patient at the early stage of adult-onset type II citrullinaemia with arginine and sodium pyruvate. J. Inherit. Metab. Dis. 2008, 31, S343-S347. [CrossRef]

70. Saheki, T.; Inoue, K.; Tushima, A.; Mutoh, K.; Kobayashi, K. Citrin deficiency and current treatment concepts. Mol. Genet. Metab. 2010, 100, S59-S64. [CrossRef]

71. Saheki, T.; Inoue, K.; Ono, H.; Katsura, N.; Yokogawa, M.; Yoshidumi, Y.; Furuie, S.; Kuroda, E.; Ushikai, M.; Asakawa, A.; et al. Effects of supplementation on food intake, body weight and hepatic metabolites in the citrin/mitochondrial glycerol-3-phosphate dehydrogenase double-knockout mouse model of human citrin deficiency. Mol. Genet. Metab. 2012, 107, 322-329. [CrossRef]

72. Saheki, T.; Moriyama, M.; Kuroda, E.; Funahashi, A.; Yasuda, I.; Setogawa, Y.; Gao, Q.; Ushikai, M.; Furuie, S.; Yamamura, K.; et al. Pivotal role of inter-organ aspartate metabolism for treatment of mitochondrial aspartate-glutamate carrier 2 (citrin) deficiency, based on the mouse model. Sci. Rep. 2019, 9, 4179. [CrossRef] 
73. Moriyama, M.; Li, M.X.; Kobayashi, K.; Sinasac, D.S.; Kannan, Y.; Iijima, M.; Horiuchi, M.; Tsui, L.C.; Tanaka, M.; Nakamura, Y.; et al. Pyruvate ameliorates the defect in ureogenesis from ammonia in citrin-deficient mice. J. Hepatol. 2006, 44, 930-938. [CrossRef] [PubMed]

74. Stoll, B.; McNelly, S.; Buscher, H.P.; Häussinger, D. Functional hepatocyte heterogeneity in glutamate, aspartate and alpha-ketoglutarate uptake: A histoautoradiographical study. Hepatology 1991, 13, 247-253. [CrossRef]

75. Neame, K.D.; Wiseman, G. The transamination of glutamic and aspartic acids during absorption by the small intestine of the dog in vivo. J. Physiol. 1957, 135, 442-450. [CrossRef] [PubMed]

76. Parsons, D.S.; Volman-Mitchell, H. The transamination of glutamate and aspartate during absorption in vitro by small intestine of chicken, guinea-pig and rat. J. Physiol. 1974, 239, 677-694. [CrossRef] [PubMed]

77. Windmueller, H.G.; Spaeth, A.E. Metabolism of absorbed aspartate, asparagine, and arginine by rat small intestine in vivo. Arch. Biochem. Biophys. 1976, 175, 670-676. [CrossRef]

78. Hoshi, M.; Mukai, S.; Shinzawa, J.; Watanabe, S.; Kasukawa, R.; Orikasa, H.; Kobayashi, K.; Saheki, T. A case of adult-onset type II citrullinemia in which oral administration of L-arginine granules improved the patient's encephalopathy and the increased level of ammonia. Kanzo 2002, 43, 492-497. [CrossRef]

79. Yazaki, M.; Kinoshita, M.; Ogawa, S.; Fujimi, S.; Matsushima, A.; Hineno, A.; Tazawa, K.; Fukushima, K.; Kimura, R.; Yanagida, M.; et al. A 73-year-old patient with adult-onset type II citrullinemia successfully treated by sodium pyruvate and arginine. Clin. Neurol. Neurosurg. 2013, 115, 1542-1545. [CrossRef]

80. Okano, Y.; Ohura, T.; Sakamoto, O.; Inui, A. Current treatment for citrin deficiency during NICCD and adaptation/compensatin stages: Strategy to prevent CTLN2. Mol. Genet. Meatab. 2019, 127, 175-185. [CrossRef]

81. Hayasaka, K.; Numakura, C.; Toyota, K.; Kakizaki, S.; Watanabe, H.; Haga, H.; Takahashi, H.; Takahashi, Y.; Kaneko, M.; Yamakawa, M.; et al. Medium-chain triglyceride supplementation under a low-carbohydrate formula is a promising therapy for adult-onset type II citrullinemia. Mol. Genet. Metab. Rep. 2014, 1, 42-50. [CrossRef]

82. Saheki, T.; Funahashi, A.; Kuroda, E.; Yasuda, I.; Gao, Q.; Setogawa, Y.; Ushikai, M.; Horiuchi, M.; Moriyama, M. Effect of MCT on hyperammonemia in citrin deficiency. In Japanese Journal for Inherited Metabolic Diseases Volume 35, Akita, Japan, 24-26 October 2019; LETTERPRESS: Hiroshima, Japan, 2019; p. 159.

83. Moriyama, M.; Kuroda, E.; Funahashi, A.; Yasuda, I.; Gao, Q.; Setogawa, Y.; Ushikai, M.; Horiuchi, M.; Saheki, T. Effect of MCT on ureagenesis from ammonia in perfused liver of citrin-deficiency model mouse. Japanese Journal for Inherited Metabolic Diseases Volume 35, Akita, Japan, 24-26 October 2019; LETTERPRESS: Hiroshima, Japan, 2019; p. 157.

(C) 2020 by the authors. Licensee MDPI, Basel, Switzerland. This article is an open access article distributed under the terms and conditions of the Creative Commons Attribution (CC BY) license (http://creativecommons.org/licenses/by/4.0/). 